\title{
Oxygen dynamics in choanosomal sponge explants
}

\section{Friederike Hoffmann, Ole Larsen , Hans Tore Rapp \& Ronald Osinga}

To cite this article: Friederike Hoffmann, Ole Larsen , Hans Tore Rapp \& Ronald Osinga (2005) Oxygen dynamics in choanosomal sponge explants, Marine Biology Research, 1:2, 160-163, DOI: 10.1080/17451000510019006

To link to this article: https://doi.org/10.1080/17451000510019006

$$
\text { 曲 Published online: } 18 \text { Feb } 2007 .
$$

Submit your article to this journal $\sqsubset$

$$
\text { Џ Article views: } 215
$$

Q View related articles $\square$

Citing articles: 32 View citing articles 


\title{
SHORT COMMUNICATION
}

\section{Oxygen dynamics in choanosomal sponge explants}

\author{
FRIEDERIKE HOFFMANN ${ }^{1,2}$, OLE LARSEN ${ }^{2,3}$, HANS TORE RAPP $^{4} \&$ \\ RONALD OSINGA ${ }^{5}$
}

${ }^{1}$ Department of Geosciences, Geobiology Group, University of Göttingen, Goldschmidtstr. 3, 37077 Göttingen, Germany, ${ }^{2}$ Max Planck Institute for Marine Microbiology, Celsiusstr. 1, 28359 Bremen, Germany, ${ }^{3}$ DHI Water and Environment, Krusenberg 31, 28857 Syke, Germany, ${ }^{4}$ Department of Biology, University of Bergen, P.O. Box 7800, Høyteknologisenteret, 5020 Bergen, Norway and ${ }^{5}$ Fish Culture and Fisheries Group, Wageningen University and Research Centre, P.O. Box 338, 6700 AH Wageningen, The Netherlands

\begin{abstract}
Oxygen microprofiles were measured over the boundary layer and into the tissue of 10-day-old cultivated tissue fragments (explants of $2-4 \mathrm{~cm}^{3}$ ) from the choanosome of the cold-water sponge Geodia barretti with oxygen-sensitive Clark-type microelectrodes. At this time of cultivation, the surface tissue and the aquiferous system of the explants is regenerating, which makes oxygen and nutrient supply by pumping activity impossible. Oxygen profiles showed a parabolic shape, indicating oxygen flux over a diffusive boundary layer and into the tissue. Oxygen was always depleted only $1 \mathrm{~mm}$ below the sponge surface, leaving the major part of the explants anoxic. Diffusive oxygen flux into the explant was calculated from three oxygen profiles using Fick's first law of diffusion and revealed $9 \mu \mathrm{mol} \mathrm{O}_{2} \mathrm{~cm}^{-3}$ day $^{-1}$, which is in the lower range of in situ oxygen consumption of whole sponges. The ability of $G$. barretti to handle continuous tissue anoxia enables choanosomal explants to survive the critical first weeks of cultivation without a functional aquiferous system, when oxygen is supplied to the sponge explant by molecular diffusion over its surface.
\end{abstract}

Key words: Geodia barretti, microelectrodes, oxygen consumption, oxygen profiles, sponge cultivation

\section{Introduction}

Sponges are sedentary filter-feeding organisms with a simple body plan built around a system of water canals. They obtain organic carbon and oxygen from the ambient water filtered through the sponge body by flagellated cells, choanocytes, which are gathered in choanocyte chambers. Pores for incurrent water and exhalant openings (osculi) are scattered over the sponge surface. Sponges with a functional canal system react to environmental changes with modulation of the pumping rate, and can also stop pumping for several hours (Reiswig 1971; Vogel 1977; Gerodette \& Flechsig 1979; Pile et al. 1997). Sponges usually use only a small fraction of oxygen in the filtrated water for respiration (e.g. Reiswig 1971, 1974; Osinga et al. 2001). Numerous sponges are associated with large amounts of micro-organisms (Vacelet \& Donadey 1977; Hentschel et al.
2003), which also include anaerobic microbes (Santavy et al. 1990; Schumann-Kindel et al. 1997; Webster et al. 2001; Hoffmann et al. 2005). In direct comparison, Reiswig $(1974,1981)$ reported a higher oxygen demand of bacteriosponges than of non-bacteriosponges.

Many marine sponges produce secondary metabolites with potential interest to society. Limited possibilities for supply of these compounds from natural resources often delay or even stop further development of a product after its initial discovery (Munro et al. 1999; Pomponi 1999; Faulkner 2000). This has led to an increased interest in the biotechnological production of sponge tissue. The cultivation of sponge tissue samples (explants) in both land- and sea-based aquaculture seems to be the most successful technique at present (Osinga et al. 1999; Belarbi et al. 2003). The first weeks are the most sensitive phase in aquaculture initiation of

Correspondence: F. Hoffmann, Max Planck Institute for Marine Microbiology, Celsiusstr. 1, DE-28359 Bremen, Germany. E-mail: fhoffman@mpi-bremen.de

Published in collaboration with the University of Bergen and the Institute of Marine Research, Norway, and the Marine Biological Laboratory, University of Copenhagen, Denmark 
sponges (Pronzato et al. 1999; De Caralt et al. 2003; Hoffmann et al. 2003b; Nickel \& Brümmer 2003). Commonly, explants for sponge aquaculture contain at least a part of old surface (ectosome) with pores and osculi (e.g. Bavestrello et al. 1998; Müller et al. 1999; Nickel \& Brümmer 2003). Connes (1966) observed that explants cut entirely from the choanosome failed to survive. However, Hoffmann et al. (2003b) observed the opposite in cultivated fragments of Geodia barretti Bowerbank, 1858, a bacteriosponge that produces bioactive secondary metabolites (Sölter et al. 2002; Sjögren et al. 2004). Choanosomal tissue fragments of this species cut at least $2 \mathrm{~cm}$ away from the sponge surface were successfully cultivated with regeneration of a functional aquiferous system after 1 year of cultivation, while those including old surface died within a few days.

In contrast to explants containing at least a part of the old ectosome, choanosomal explants show healing processes over the entire surface; a new ectosome with pores and osculi has to regenerate from choanosomal tissue. It is unclear how and if those explants are capable of water pumping until new pores and osculi have been formed.

\section{Materials and methods}

In order to investigate the mechanism of oxygen supply to explants in this critical phase of cultivation, oxygen profiles with $50 \mu \mathrm{m}$ resolution over the boundary layer and in the tissue of sponge explants were measured with oxygen-sensitive Clark-type microelectrodes (Clark et al. 1953; Revsbech \& Jørgensen 1986), as described by Schönberg et al. (2004). After profiling, the sponge fragments were kept in cultivation systems for another 2 days, and were then fixed in $2 \%$ formaldehyde $/ 0.04 \%$ glutaraldehyde in filter sterilized seawater. Microscopic sections were prepared from tissue blocks embedded in LR White or paraffin, as described by Hoffmann et al. (2003a).

The sponges used for the experiments were sampled near the city of Bergen on the west coast of Norway, between 100 and $200 \mathrm{~m}$ depth on a hard bottom slope in Korsfjord $\left(60^{\circ} 09^{\prime} 12^{\prime \prime} \mathrm{N} 05^{\circ} 08^{\prime} 52^{\prime \prime} \mathrm{E}\right)$ in October 2001. Cube- or cuboid-shaped fragments of $2-4 \mathrm{~cm}^{3}$ (i.e. edge length of $1-2 \mathrm{~cm}$ ) were cut from the choanosomal tissue of freshly retrieved G. barretti and kept in half-open cultivation systems with unfiltered seawater, as described by Hoffmann et al. (2003b). Sponge explants were placed on finemesh plastic grids $(3 \mathrm{~mm}$ mesh) with no artificial connection, allowing the entire surface to be in contact with the ambient water. Explants showing good surface regeneration and no signs of decay were used for oxygen profiling after 10 days of cultivation.

\section{Results}

Three oxygen profiles were obtained from two different sponge explants. The profiles showed a parabolic shape (see Figure 1). Oxygen was always depleted between 0.5 and $1 \mathrm{~mm}$ below the sponge surface, leaving the major part of the explants anoxic. From the diffusive boundary layer above the sponge surface, vertical concentration gradients of oxygen $(\mathrm{dc} / \mathrm{dz})$ were calculated, which ranged between 0.16 and $0.2 \mu \mathrm{M} \mathrm{O}_{2} \mu \mathrm{m}^{-1}$, mean $=0.18$.

The explants used for the experiments did not show any signs of decay 2 days after profiling, and microscopic investigation showed good tissue regeneration. The cut surfaces were covered with a transparent "skin" of cells (observation by eye). The massive accumulation of cells with inclusions and motile sponge cells, as well as the presence of degenerated choanocyte chambers, indicated tissue remodelling in the superficial layer of the explants (microscopic observation).

\section{Discussion}

When explants of $G$. barretti die, the tissue turns black, exhibits a sulphidic smell and is quickly covered by a slimy white mat of microbes and protists (pers. obs.). This happens within a few hours. The explants used for oxygen profiling did not show these features within 2 days following the experiments. The regeneration processes observed in microscopic tissue sections were typical for healthy explants after 10 days of cultivation (Hoffmann et al. 2003b). We therefore conclude that the sponge explants were in a good condition during the experiments.

The oxygen profiles show that most tissue parts of the explants were permanently without free oxygen. The shape of the oxygen profiles is similar to those obtained from undisturbed marine sediments (Revsbech \& Jørgensen 1986; Rasmussen \& Jørgensen 1992). This indicates continuous diffusive flux into the sponge tissue, with no pumping activity involved. Oxygen is supplied to the sponge explant by molecular diffusion over a diffusive boundary layer. In contrast, microprofiles of actively pumping whole sponges show a combination of diffusive and advective flux (Hoffmann et al. 2005). Microprofiles are commonly used in aquatic sciences to calculate diffusive fluxes using Fick's first law of diffusion (Jørgensen \& Revsbech 1985; Rasmussen \& Jørgensen 1992; De Beer 2001; Røy et al. 2002). Using the mean vertical concentration gradient of oxygen as 

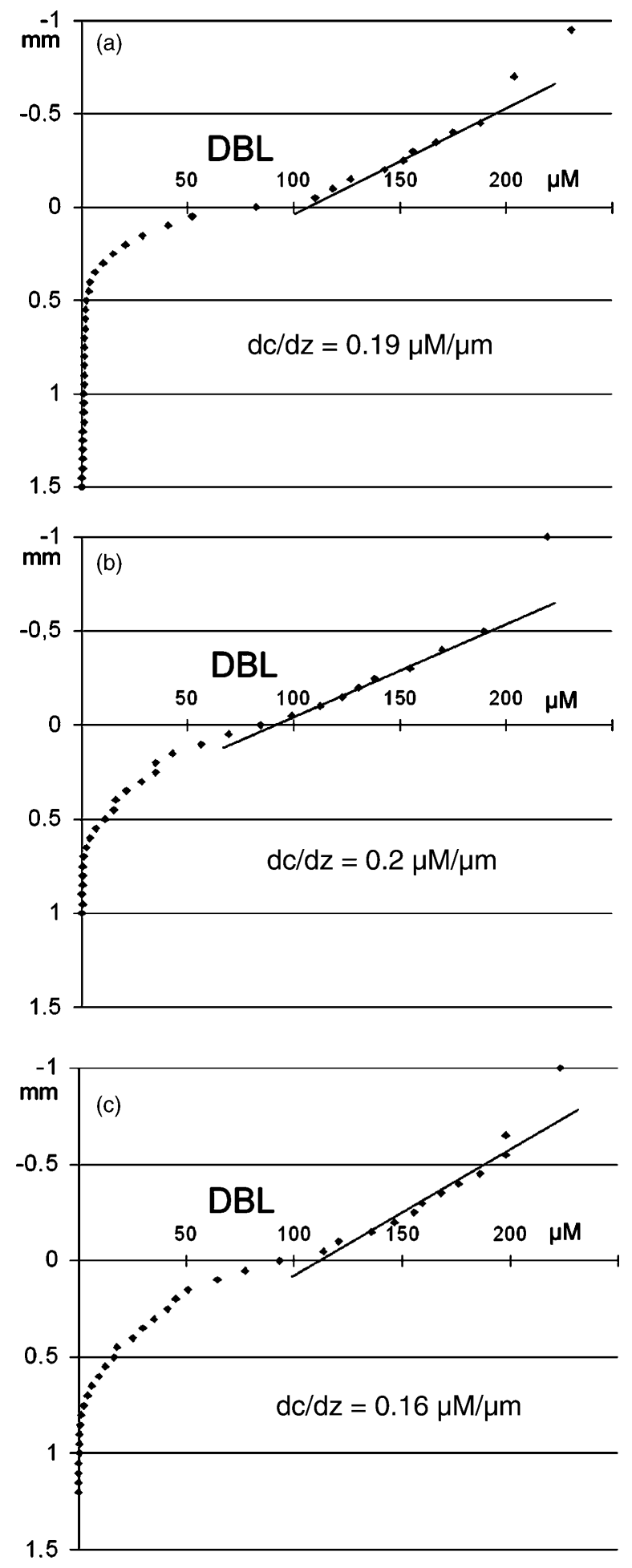

Figure 1. Oxygen microprofiles measured in 10-day-old explants of Geodia barretti. The parabolic shape of the profiles indicates oxygen flux over a diffusive boundary layer (DBL) and into the sponge tissue. A linear slope was fitted to the oxygen gradient measured within the DBL and was used to calculate the diffusive oxygen uptake rate $(\mathrm{dc} / \mathrm{dz})$ of the sponge explants. (a) explant 1 , (b, c) explant 2.

obtained from the profiles $\left(0.18 \mu \mathrm{M} \mathrm{O}_{2} \mu \mathrm{m}^{-1}\right)$, an oxygen flux into the explant over its surface of 2.27 $\mu \mathrm{mol} \mathrm{O}_{2} \mathrm{~cm}^{-2} \mathrm{day}^{-1}$ was calculated. Assuming an even diffusive flux over the entire surface, the total oxygen consumption of sponge explants with $1.5 \mathrm{~cm}$ edge length (surface area $13.5 \mathrm{~cm}^{2}$, volume 3.38 $\mathrm{cm}^{3}$ ) was $9.07 \mu \mathrm{mol} \mathrm{O}_{2} \mathrm{~cm}^{-3}$ day $^{-1}$. In situ oxygen consumptions of sponges, as obtained from bulk measurements, range between 4.8 and $600 \mu \mathrm{mol} \mathrm{O}_{2}$ $\mathrm{cm}^{-3}$ sponge day ${ }^{-1}$ (reviewed in Osinga et al. 1999).

It can be concluded that oxygen supply by molecular diffusion over the sponge surface enables explants of $G$. barretti of the given size to exhibit an oxygen consumption rate that is in the lower range of those of whole sponges. A prerequisite is that the entire surface of the explants is in contact with the ambient water, which must be of good quality. This is consistent with observations from cultivation experiments (Hoffmann et al. 2003b). Although the diffusive flux of oxygen can balance the sponge's overall oxygen demand, the largest part of the explant is permanently anoxic. Obviously, this species can handle this situation well. Hypoxic and anoxic conditions have also been described in the tissue of actively pumping $G$. barretti (Hoffmann et al. 2005), as well as in primmorph cultures of Suberites domuncula (Gatti et al. 2002). Associated anaerobic sponge microbes may benefit from these conditions. However, tissue anoxia was assumed to be temporary, depending on the pumping activity of the sponge (Hoffmann et al. 2005) or the current velocity around the primmorph (Gatti et al. 2002). The ability of $G$. barretti to handle continuous tissue anoxia allows choanosomal explants of this species to survive the critical first weeks of cultivation until regeneration of the aquiferous system is completed. During this time, oxygen is supplied by molecular diffusion over the sponge surface.

\section{Acknowledgements}

Thanks are due to the crew of R/V Hans Brattström and the Marine Biological Station of Bergen University. Access to these installations has been supported by the IHP (Improving Human Research Potential) Programme from the European Union through contract no. HPRI-CT-1999-00056. This paper represents publication no. 42 of the research programme BOSMAN (03F0358A and C). Financial support was provided by the Bundesministerium für Bildung und Forschung (BMBF), Germany. We thank Wolfgang Dröse for the preparation of histological sponge sections, and Andreas Reimer for assistance with flux calculations. 


\section{References}

Bavestrello G, Benatti U, Calcinai B, Catteneo-Vietti R, Cerrano C, Favre A, Giovine M, Lanza S, Pronzato R, Sara M. 1998. Body polarity and mineral selectivity in the demosponge Chondrosia reniformis. Biological Bulletin 195:120-5.

Belarbi EH, Gómez AC, Chisti Y, Camacho FG, Grima EM. 2003. Producing drugs from marine sponges. Biotechnology Advances 21:585-98.

Clark LC, Wolf R, Granger D, Taylor A. 1953. Continuous recording of blood oxygen tension by polarography. Journal of Applied Physiology 6:189-93.

Connes R. 1966. Aspects morphologiques de la régénération de Tethya lyncurium Lamarck. Bulletin de la Société Zoologique de France 91:43-53.

De Beer D. 2001. Microsensor studies of oxygen, carbon and nitrogen cycles in lake sediments and microbial mats. In: Taillefert M, Rozan TF, editors. Environmental Electrochemistry: Analyses of Trace Element Biogeochemistry. Washington: American Chemical Society Symposium Series 811. p 227-46.

De Caralt S, Agell G, Uriz M-J. 2003. Long-term culture of sponge explants: conditions enhancing survival and growth, and assessment of bioactivity. Biomolecular Engineering 20(46):339-47.

Faulkner J. 2000. Marine pharmacology. Antonie van Leeuwenhoek 77:135-45.

Gatti S, Brey T, Müller WEG, Heilmayer O, Holst G. 2002. Oxygen microoptodes: a new tool for oxygen measurements in aquatic animal ecology. Marine Biology 140:1075-85.

Gerodette T, Flechsig AO. 1979. Sediment-induced reduction in the pumping rate of the tropical sponge Verongia lacunosa. Marine Biology 55:103-10.

Hentschel U, Fieseler L, Wehrl M, Gernert C, Steinert M, Hacker J, Horn M. 2003. Microbial diversity of marine sponges. In: Müller WEG, editor. Marine Molecular Biotechnology. Berlin: Springer. p 59-88.

Hoffmann F, Janussen D, Dröse W, Arp G, Reitner J. 2003a. Histological investigation of organisms with hard skeletons: a case study of siliceous sponges. Biotechnic and Histochemistry $78(3-4): 191-9$

Hoffmann F, Larsen O, Thiel V, Rapp HT, Pape T, Michaelis W, Reitner J. 2005. An anaerobic world in sponges. Geomicrobiology Journal 22(1)

Hoffmann F, Rapp HT, Zöller T, Reitner J. 2003b. Growth and regeneration in cultivated fragments of the boreal deep water sponge Geodia barretti Bowerbank, 1858 (Geodiidae, Tetractinellida, Demospongiae). Journal of Biotechnology 100(2): $109-18$.

Jørgensen BB, Revsbech NP. 1985. Diffusive boundary layers and the oxygen uptake of sediments and detritus. Limnology and Oceanography 30:111-22.

Müller WEG, Wimmer W, Schatton W, Böhm M, Batel R, Filic Z. 1999. Initiation of an aquaculture of sponges for the sustainable production of bioactive metabolites in open systems: example, Geodia cydonium. Marine Biotechnology 1:569-79.

Munro MHG, Blunt JW, Dumdei EJ, Hickford SJH, Lill RE, Li S, Battershill CN, Duckworth AR. 1999. The discovery and development of marine compounds with pharmaceutical potential. Journal of Biotechnology 70:15-25.

Nickel M, Brümmer F. 2003. In vitro sponge fragment culture of Chondrosia reniformis (Nardo, 1847). Journal of Biotechnology 100:147-59.
Osinga R, Kleijn R, Groenendijk E, Niesinck P, Tramper J, Wijffels RH. 2001. Development of in vivo sponge cultures: particle feeding by the tropical sponge Pseudosuberites aff. andrewsi. Marine Biotechnology 3:544-54.

Osinga R, Tramper J, Wijffels RH. 1999. Cultivation of marine sponges. Marine Biotechnology 1:509-32.

Pile AJ, Patterson MR, Savarese M, Chernykh VI, Fialkov VA. 1997. Trophic effects of sponge feeding within Lake Baikal's littoral zone. 1. In situ pumping rate. Limnology and Oceanography $42(1): 171-8$.

Pomponi SA. 1999. The bioprocess-technological potential of the sea. Journal of Biotechnology 70:5-13.

Pronzato R, Bavestrello G, Cerrano C, Magnino G, Manconi R, Pantelis J, Sarà A, Sidri M. 1999. Sponge farming in the Mediterranean Sea: new perspectives. Memoirs of the Queensland Museum 44:485-91.

Rasmussen H, Jørgensen BB. 1992. Microelectrode studies of seasonal oxygen uptake in a coastal sediment: role of molecular diffusion. Marine Ecology Progress Series 81:289-303.

Reiswig HM. 1971. In situ pumping activities of tropical Demospongiae. Marine Biology 9:38-50.

Reiswig HM. 1974. Water transport, respiration and energetics of three tropical marine sponges. Journal of Experimental Marine Biology and Ecology 14:231-49.

Reiswig HM. 1981. Partial carbon and energy budgets of the bacteriosponge Verongia fistularis (Porifera: Demospongiae) in Barbados. Marine Ecology Progress Series 2:273-93.

Revsbech NP, Jørgensen BB. 1986. Microelectrodes: their use in microbial ecology. Advances in Microbial Ecology 9:293-352.

Røy H, Hüttel M, Jørgensen BB. 2002. The role of small-scale sediment topography for oxygen flux across the diffusive boundary layer. Limnology and Oceanography 47(3):837-47.

Santavy DL, Willenz P, Colwell RR. 1990. Phenotypic study of bacteria associated with the Caribbean sclerosponge, Ceratoporella nicholsoni. Applied and Environmental Microbiology 56:1750-62.

Schönberg CHL, Hoffmann F, Gatti S. 2004. Using microsensors to measure sponge physiology. Bollettino dei Musei e degli Istituti Biologici dell' Universitá die Genova 68:593-604.

Schumann-Kindel G, Bergbauer M, Manz W, Szewyk U, Reitner J. 1997. Aerobic and anaerobic microorganisms in modern sponges: a possible relationship to fossilization processes. Facies 36:268-72.

Sjögren M, Göransson U, Johnson A-L, Dahlström M, Andersson R, Bergman J, Jonsson PR, Bohlin L. 2004. Antifouling activity of brominated cyclopeptides from the marine sponge Geodia barretti. Journal of Natural Products 67(3):368-72.

Sölter S, Dieckmann R, Blumenberg M, Francke W. 2002. Barettin, revisited? Tetrahedron Letters 43(18):3385-6.

Vacelet J, Donadey C. 1977. Electron microscope study of the association between some sponges and bacteria. Journal of Experimental Marine Biology and Ecology 30:301-14.

Vogel S. 1977. Current-induced flow through living sponges in nature. Proceedings of the National Academy of Science USA 74(5):2069-71.

Webster NS, Watts JEM, Hill RT. 2001. Detection and phylogenetic analysis of novel Crenarcheote and Euryarcheote 16S ribosomal RNA gene sequence from a Great Barrier Reef sponge. Marine Biotechnology 3:600-8.

Editorial responsibility: Tom Fenchel 